\title{
Functioning of Autobiographical Memory as a Discursive Phenomenon ${ }^{1}$
}

Larisa N. Rebrina

Dr. hab., Volgograd State University

Email:Reblora@mail.ru

Anna A. Petrova

Dr. hab., Volgograd State University

Email: petrova16@mail.ru

Nikolai L. Shamne

Dr. hab., Volgograd State University

Email:shamnenl@gmail.com

Elena Yu. Ladonina

PhD, Volgograd State University

Email: elena_ladonina@mail.ru

Marina V. Milovanova

Dr. hab., Volgograd State University

Email:milovanovamv05@yandex.ru

Doi:10.5901/mjss.2015.v6n5p122

\section{Abstract}

The article investigates the discursive manifestation of autobiographical memory, enabling to understand the social and communicative nature of this phenomenon. Autobiographical practices represent the social and cultural materialized form of the fixation of autobiographical memory determined by speech norms and memory mechanisms; autobiographical practices are inter-active and inter-subjective, mediate the formation and functioning of this subsystem of memory, reorganizing the preverbal event of the individual past through the concepts fixed by language. The article examines the development of autobiographical memory forms in early ontogeny, the relationship of these processes with the formation of speech and discursive competences. It studies the patterns of discursive actualization of the formed autobiographical memory and demonstration of its functional and structural characteristics. It is shown that the formed autobiographical memory as a personality-cognitive system organizes and arranges the fragments of the individual past; it is involved in the formation of self-identity, has a layered structure that is related to heterogeneous forms of processing autobiographical material and organizational forms of individual experience and performs different functions, all of which determines the patterns of respective discursive practices.

Keywords: autobiographical memory; development of the memory forms; discursive practices; organizational forms of the autobiographical material; layered structure of the autobiographical memory; thematic keynotes; autobiographical memory functions.

\section{Introduction}

Memory represents an actively developed object in the interdisciplinary studies that is conditioned by the significance, complexity and multidimensionality of the phenomenon which is functioned as at the level of the society and at the level of the individual. The social, communicative and semiotic nature of memory, its mainly linguistic manifestation enables to state the cognitive potential of linguistics in this sphere and the patterns of the integration of the existing intra-disciplinary linguistic knowledge in the research paradigm of memory (Shamne, Rebrina, Milovanova, Petrova, 2014). The spectrum

1 Under the financial support of the Russian Humanitarian Scientific Fund (project 15-04-00068) 
of the memory discursive practices including the autobiographical self-presentations is continually increasing.

One of the memory subsystems underlined from the bio-psychological and sociological standpoints is autobiographical memory which performs its own functions and is characterized by the respective functional patterns. The analysis of autobiographical practices which is shown on the example of the German language enables to make meaningful researches on the functional and structural characteristics and communicative nature of autobiographical memory (AM).

We also assume the following theoretical principles. AM is long-term, individual, declarative, explicit (consciously reproducible content) memory dealt with episodic memory which includes the personally significant life events and the subject as a participant or witness of the events. Autobiographical memory exists in the mental chronotope (the mental space and time of the personality-cognitive meanings); supposes the active adaptation to the actual individual needs, social context (Baddeley, 1992; Conway, 1993); plays the important role in the personal identity structure as the result of the socialization, individualization and combination of social identity (the social rules interiorized by personality, involvement in social groups) and self-identity. Self-identity can be personal (the emotional experience of knowledge on individual, psychological, behavioral, physical characteristics) and autobiographical (the emotional experience of the unity of personal life, the continuity of life periods) (Nurkova, 2004: 78). All types of identity are supposed to appeal to AM. AM can exist in a verbal form (a narrative organization); it is characterized by the attributive content as a personal one; the specific time organization of the material; the emotional and motivational, social and cultural conditionality. Autobiographical memory is regulated by the complementary principles of compliance (reflects the life experience) and coherence (is correlated with other memories and the vision of the individual himself) (Blagutina, 2009). AM is a personality-cognitive system managed by the actual needs of the subject, mediated by social and cultural means such as narrative structures, life scenarios, finding out the specifics in ontogeny, originating as an inter-psychic function in the form of sharing actualization and developing in an intra-psychic function (Nurkova, 2008: 17-18, 2004: 3). This subsystem has its own functions: pragmatic, self-regulatory, communicative, existential (Vasilevskaya, 2008). Autobiographical practices represent a culturally based, socialized, mediated, materialized form of fixation of AM determined by speech norms and memory mechanisms.

\section{Material and Methods}

To achieve the aim, analyze the development of autobiographical memory forms, describe communicative nature and discursive aspects of its functioning, the following research problems are to be solved within the investigation:

I. the study of the development of autobiographical memory form and the overcoming of child's amnesia in the early period of ontogeny;

II. The study of the patterns of discursive actualization of the formed autobiographical memory and organizational forms of individual experience, the discursive manifestation of functional and structural characteristics of AM.

The stated research problems provide the following research steps:

I. When analyzing the development of autobiographical memory forms on early stages: 1) the study of videoand audio-recordings and transcripts of conversations of adults with a child; 2) the detailed description of discursive practices with the definition of communicative status of responses of a child and adult, and identification of strategic and tactical methods of the latter, facilitating the overcoming of child's amnesia.

II. When analyzing the discursive actualization of the formed AM of an adult and manifestation of AM functional and structural characteristics in respective discursive practices: the study 1) of the discursive manifestation of the forms of processing autobiographical material; 2) the objectivity of the layered structure of $A M$ in autobiographical practices; 3) the thematic keynotes of discursive re-actualization of the individual past; 4) the discursive manifestation of AM functions.

III. Audio- and video-recordings of communication with the German-speaking preschoolers aged 2 to 7 years were served as the material of the linguistic study of memory in early ontogeny; multimedia case data, e.g. CHILDES Transcript Browser (CHILDES) with speech transcripts of the German-speaking children aged 3 to 7 years, as well as personal audio- and videos were used.

IV. The study represents the initial statements of the subject assuming the formation of individual experience in chronological and thematic sequence and identification of individual regular characteristics and incentives. The data of the German language archive from the Institute of the German language in Mannheim were used as the main sources. The material in cases is presented in the most "natural" form that means the minimum outside influence and the inclusion of not only linguistic, verbal and non-verbal (intonation, emphasis, etc.), but also extra-linguistic information (pauses, sighs, laughter, coughing, etc.). We also consider that the form of 
narrative is correlated with the structure of life experience, and the reminiscing subject himself having an unprepared statement is less prone to self-presentation, and that the patterns of communicative practices are characterized by the desire of the respondent for the integrity and completeness of the narrative about the episodes of his life; by the concentration, i.e. the selectivity of reproduction of the past experience; the orientation to subjectively significant events and their details; the authenticity of reproduction of autobiographical experience (the congruence of personality and individual life story).

The selected methodology allows us to consider AM as a construct, show the relationship of the AM formation and functioning with the development of the discursive competence, the personality and cognitive system and changes of the social factors in the process of socialization, reveal the functional and structural characteristics of AM.

\section{Results}

When studying the genesis of the various subsystems of long-term memory we relied on the concept of K. Nelson, V.V. Nurkova, V. Rotenberg. The model of long-term memory includes three subsystems: episodic, general and autobiographical. According to K. Nelson, the first memory developed in ontogeny is episodic one having a buffer nature and fixing specific episodes. As a child develops verbal thinking, episodes are summarized and their specificity is lost. By the time of the formation of autobiographical memory (the age of the earliest autobiographical memory is 3 or 4 years), a child has already had a number of specific episodes (episodic memory) and the vision of the events of human life (general memory).

The analysis of the formation of the initial layer of functioning of early involuntary forms of child's memory (Bowden, Beeman, 1998; Chernigovskaya, Deglin, 1986; Craik et al., 1999; Decety, Chaminade, 2003; Decety, Sommerviile, 2003; Devinsky, 2000; Downar et al., 2002; Keenan et al, 2001; Lou et al., 2004; Markowitsch, 1995; Platek et al., 2004; Rotenberg, Weinberg, 1999), as well as the study of the development of mnemic processes of a preschooler during discursive practices with adults shows that:

\subsection{The development of autobiographical memory forms is primarily associated with the development of speech in ontogeny especially with the formation of the competence of oral narrative.}

The formation of the competence of acquiring an oral narrative is characterized by certain ontogenetic stages and is connected not only with the acquiring of the discursive skills of a preschooler but with the improvement of child's mental operations gradually taking the form of speech. The following age layers are important for the genesis of any narrative including the narrative of a picture, retelling as a heard or seen oral reproduction, autobiographical narrative (AN): 1) the age of 3 or 4 years which is characterized by a narrative in a broad sense without a precise characteristic of the type of a narrative, in other words, it is not clear if it is a narrative, description or reproduction. The first narratives are abrupt, inconsistent and do not have a clear structure of presentation and are possible only with the support of an adult partner in communication; the chronotope of events is not explicated lexically (there are no lexical markers of chronological and spatial sequence of events such as "first, then") but is passed implicitly by making a certain event sequence with the use of the time verb-forms of Present and Perfect acquired in this age interval; 2) at the age of 5 or 6 years there is a great change in the competence of acquiring a narrative; so along with a narrative in a broad sense there is a narrative in a narrow sense in which the experienced or given event finds its clear linguistic presentation that is expressed first of all by the complicated structure and complexity in the representation of the event; there is a self-assessment of something seen or heard that is associated with the development of self-reflection and "self-concept". So, in the speech of children there are statements with emotional assessment: "and I got scared/und ich hab Angst gehabt", "it was not dangerous/das war nicht gefăhrlich", etc.; 3) at the age of 7 or 8 years a narrative-emotional experience-memory with increasing flexibility in the use of linguistic means is fixed; 4) the age interval from 9 years and onwards is characterized by increasing the diversity of emotional qualifications of a narrative, expanding the subject and predicate grid of proposals including the actant markers and connectors for the expression of the causal and temporal relationships, and the development and improvement of narrative competences.

\subsection{Autobiographical memory is developed in the communication process and the interaction with adult communication partners facilitating the acquiring of discursive competences of a child.}

Studying the genesis of autobiographical narrative, L.V. Nikanorova and V.V. Nurkova actually confirm the hypothesis of $\mathrm{K}$. Nelson on the overcoming of child's amnesia and the initial stages of early memories dating the average age of the 
first memories as 3.5 years and understanding this overcoming of child's amnesia as "the model of social interaction", i.e. the dialogue of mother and a child. In the early stages of the development of child's communication (under 3 years) the model of social interaction does not include an adequate response of a preschooler to speech incentives of an adult: the request for the narrative about the observed event remains without a response that motivates an adult intuitively and emotionally to focus the child's attention on the most important details of the past forming the certain images- and memories and thus reflecting the complex structure of autobiographical narrative.

AM represents a separate type of memory which units of organization are autobiographical memories.

The study also confirms that:

1) An adult having the formed AM translates it to a child.

2) During the interaction of a child with an adult the significance and personal meaning are complemented on a sensual basis; in this triad AM becomes an autobiographical fact (Nikanorova, 1998).

According to K. Nelson, AN consists of the description of some episodes from the recent past experience of a child, the recollection of which children are selectively forced to by adult communicants owning temporal strategies of dating the events and acquiring the skills of using them in pragmatic types of dialogues. It is also emphasized that the pragmatic type has the inhibiting development unlike the telling type of dialogue discussion facilitating the development of AM. From our point of view, the idea concerning the strategic and tactical methods of the implementation and development of a child's AM undertaken by an adult is important. It finds vivid expression during the translation of memories of an adult individual (which our further study is devoted to).

In this study the following aspects are to be under discussion: according to A.R. Alyuscheva (Alyuscheva, 2012, $w w w)$, who examines the functional characteristics of autobiographical memory and its initial functions - communicative ones, it is no doubt, a child remembers to support communication with an adult; according to V.V. Nurkova, a 2-year child tells an adult everyday routine events, - it is impossible at the early stages of ontogeny as a child has no developed speech tools for whole memories and the communication is maintained not so much through them. At the early stages of ontogeny it also seems impossible to generalize a diversity of life stories as a child has no stable chronological and spatial concepts and skills of causal generalizations which the acquiring of Present and Perfect forms and personal pronouns is belonged to (e.g. the opposition "I - we") which cannot be developed by the age of 2 years. The schemes of event-based organization of life-scenarios, which are "ideal forms" ( according to L.S. Vigotski) and interiorized and used by a child to structure autobiographical memory, are possible only at the stage of adolescent development after 6 years.

At the initial stages of the development of autobiographical memory children borrow the model of appeal to the experience which their parents present to them. It is confirmed by this study clarifying that parents are trying to conceptualize the memories of children underlying as they think the most impressive events of the recent past and using such strategy as "Tell me what you saw yesterday, where you went yesterday", and this is more a didactic type of interaction with an adult (see: Alyuscheva, Nurkova, Fivush, Bauer, Nelson), however, the constant repetition of a story about the past event told by a parent to his child was not noted in this study; at the early stages of ontogeny in spontaneous everyday conversations during everyday communication when performing certain everyday activities joint participation in the process of communication and support of such activities with verbal description rather than repeating the certain memories to a child many times are likely to be important for a parent as for a child.

Thus, according to the study, in spontaneous everyday conversations of an adult with a child when performing routine everyday activities such as joint play activity, examining and reading books, making toys and other handicrafts, when generating the joint with an adult or independent stories about autobiographical episode, the main type of the dialogue interaction in a pair of "child - adult" was a developing didactic type that is managed by a system of questions and the prompts of an adult, and gives the sense of separate action to autobiographical memory.

Audio and video recordings of spontaneous conversations of the German-speaking adult with a child and their transcripts from multimedia case CHILDES Transcript Browser (CHILDES) were served as the material for the study on the formation of oral narrative as the original form of translation of autobiographical memory and thus the overcoming of child's amnesia. The age of children is from 3 to 7 years.

Episode 1. (CHILDES, Sebastian/sb000017 - hereinafter)

The description of transcript: transcript (hereinafter) begins with listing the participants of the dialogue by age, the time of the recording and its duration, the place and situation - a summary of a conversation which we present in a brief form.

The age of a child is 3 years 4 months 7 days; in transcript (hereinafter) as CHI 3;04.07; MUT - mother; RIG - a relative of the family.

16 @Location: Wohnzimmer in der elterlichen Wohnung.

17 @Situation: Die Kinder werden getauscht. Christian wird von der Tante übernommen, Sebastian kehrt in (da)s 
Wohnzimmer zurück. Er spricht heute viel, erzählt. Wir geraten in ein ausführliches Gespräch und er berichtet eine ganze Menge herrlichen Unsinns. Wir sprechen über seine Gartenbeete und das Gemüse, das auf seinen drei Beeten wächst. Dann berichtet er von den Hasen und von Theo, der gerade auf Urlaub sei.

154 *MUT: erzähl doch mal der Frau+Rigol, was ihr Mann gestern gemacht hat.

155 *MUT: die hat das, glaub ich, noch gar nich(t) gesehen.

156 *MUT: die is(t) nach Haus gekommen, da war es dunkel.

157 *MUT: und da hat die das noch gar ni(ch)t gesehen, was der Herr+Rigol gestern früh gemacht hat.

$158{ }^{*} \mathrm{CHI}$ : die \&al [//П bei euch die verblühte Blume abdemäht [: abgemäht].

$159 \%$ xspr: \$PHO

160 *RIG: hat er das gemacht?

$161{ }^{*} \mathrm{CHI}$ : hat er.

162 *RIG: und dann <hat er> [x 2] das abgeschnitten, was rausgewachsen is(t) aus dem Garten, ge(II)@o?

163 *RIG: hat er das abgeschnitten jetzt?

$164{ }^{*} \mathrm{CHI}$ : hat (e)s abdemäht [: abgemäht].

The initial right strategic and tactical actions taken by mother to recover the memories about the past events, which a child took part in, with certain emotional support, facilitate the formation of autobiographical memory of a preschooler which can be expressed in individual responses of the latter particularly at the early stages of ontogeny. Intuitively applying the method of priming and the method of associations to create associative semantic grids which are able to intensify the process of memories and lead to the restoration of the sequence of the past events, adults design the scheme of autobiographical narrative and autobiographical memory.

Mother's responses (155-157) stimulate a child to a narrative about a single episode of the day when they were together with $\mathrm{CHI}$ visiting RIG, whose husband was cleaning the garden from overblown flowers in the afternoon, RIG did not see this as she came in the evening. Meanwhile the response «die hat das, glaub ich, noch gar nich(t) gesehen» is possibly repeated by mother intuitively creating the effect of a kind of priming, in other words, the situation with the effect of stress, which can be an impetus for episodic memory of a child. She manages to do this: a child having no skills of linked narrative explains what he saw in the garden using one response (158). The next RIG's responses perform not only the function of repetition and fixing of the last episode in the memory, but fasten the sequence of actions in the garden (162 *RIG: und dann <hat er> [x 2] das abgeschnitten, was rausgewachsen is(t) aus dem Garten, ge(II)@o?), making the scheme of narrative in the certain sequence and verbalizing memories of a child. It is necessary to determine the content of memories by the structure of narrative. When verbalizing the past episode it should fit the scheme of narrative: who did, what he did, where, when, what for, why, context. If the distribution of memories in these grids initially wrong, the memories will remain false.

It is easy to notice that almost all of the episodes begin with mother's request to tell about what happened yesterday, what a child saw yesterday and what he has seen today, and what joint activity with an adult he had: MUT: wollt(e)st (d)e [: du] der Frau+Rigol eigentlich auch erzählen, was mir [: wir] für (de)n Papa für Kuchen gebacken haben; MUT: +< kannst doch ma(l) der Frau+Rigol erzählen, was ihr gestern und heut(e) im Kindergarten gemacht habt; MUT:kannst du ma(l) erzählen, was ich dir für einen geschenkt hab; MUT: hast der Frau+Rigol erzählt, was sich de(r) Papa da geleistet hatte?, etc. However, she repeatedly changes and narrows the angle of memories focusing a preschooler on the main point; thus the marker what/was acquires the contours of the center of the past episode.

From our point of view, such mother's tactics by its pragmatic type is not implicitly "forced" (according to K. Nelson, see above), but it invites a child to joint cognitive activity: the reproduction of the individual past episode. We consider the following aspects important: one episode is always reproduced from the recent past which is lexically marked as gestern and used with such chronological marker as heut(e); thus the structure of future narrative is formed explicitly: what/was, who/ihr, when=yesterday and today=, where did/gestern und heut(e) im Kindergarten gemacht habt. The components "what for, why, context" at this stage of ontogeny are not used as they are referred to causal representations and formed later.

Here we also consider to stress that the scheme of narrative, in other words, the sequence - who did, what he did, where, when, what for, why, context - can be changed depending on the grammatical and syntactic norms of any language. For example, the following subject-predicative-actant structure of a statement semantically marking the structure of memories is prevailed in the speech of the German-speaking mother in our episodes: MUT: $+<$ kannst doch ma(l) der Frau+Rigol erzählen, was ihr gestern und heut(e) im Kindergarten gemacht habt - what, who, when, where did. We think that such sequence does not break memories as it fixes or creates the individual semantic grid which having acquired will be the core of any memory - true but not false - in preschooler's mind.

Episode 2. 
CHI 6; 09.11; RIG - a relative of the family

16 @Location: Spielzimmer RIG.

17 @Situation: Langes, einleitendes Gespräch über die Krankheit der Zuchthasen, über die Betätigung bei Marvin und über die Schule.

394 *RIG: jetz(t) warst de [: du] bei (de)m Marvin zu Besuch, ja?

395 *RIG: habt ihr denn da was Schönes unternommen gemeinsam?

396 *CHI: +< ja , erst war(en) mer [: wir] draussen un(d) ham [: haben], äh@o, gearbeitet.

$397{ }^{*} \mathrm{CHI}$ : die kleine(n) Steinche(n) aus de $(m)$ Stall.

$398{ }^{*} \mathrm{CHI}$ : der Opa macht doch de(n) Garte(n)pfad neu.

$399 *$ RIG: ah_so@o,xxx.

$400{ }^{*} \mathrm{CHI}:+<$ un(d) da ha(ben) mer [: wir] die kleinen Steinche(n) rausgelese(n) aus de(m) gro(sse), wo die grosse(n) Steine noch dabei waren.

$401 \% x$ spr: \$SGF \$NS

402 *RIG: +< da seid ihr ja mordstüchtig.

403 *CHI: dann ha(ben) mer [: wir] mein(en) Rasenmäherhefte vom Obi angeguckt.

$404{ }^{*} \mathrm{CHI}$ : eigentlich wollt(e) ich heut(e) zwei mitbringen, zwei andere vom Wolfgang.

$405{ }^{*} \mathrm{CHI}$ : nur ich hab(e) (e)s net [: nicht] geschafft.

In fact, we see a free and consistent child's narrative of the past events made with different syntactic patterns including the introductive and postpositive actualizors. The initial responses of an adult $(394,395)$ are usually the incentive to revive memories and aimed at the key aspects of the development of such child's autobiographical narratives. At the age of 6 or 7 years, as the study shows, a child alone is able to develop and actualize the key forms of his autobiographical narrative.

The age of 4 years is likely to be a critical stage in the formation of memories as autobiographical ones and of giving them the form of autobiographical narrative.

The age interval from 9 years and onwards is characterized by expanding of the subject and predicate grid of statements for the expression of the causal, and chronological and spatial relationships in the translating of the past events and, as a consequence, by developing and improving teenager's narrative competences.

3.3 In discursive practices the different organizational forms of autobiographical material and layered structure of AM are manifested, the semantic processing of the individual past determines its discursive re-actualization.

The analysis of the discursive manifestations of the formed AM confirms the theses of psychologists on heterogeneous forms of processing autobiographical material in AM, constituting by such "impressive", "important", "crucial", essential events" (Nurkova, 2008). The quantitative estimates in the studied texts indicate the prevailing manifestation of reactualizing impressive, single events (62.12\%), the less verbalizing of memories about important (13.95\%), essential $(16.28 \%)$ and crucial events (4.65\%).

The manifestation of impressive event is characterized by dynamic and emotional description, the reproduction of time and space characteristics of situation, the reconstruction of a whole picture of the event as emotional and semantic interpretation. The re-actualization of important events includes the analysis of their consequences and role in author's life, the correlation with a certain life theme, and also the emotional experience of the relationship of a fragment of the past to the current situation, individual motives and needs, the retrospective from today, the vast time prospect covering relatively large thematically united time intervals. The re-actualization of essential events as a kind of generalizing congruent metaphor of personality has the verbalized experiences of identity, the comparison of the characteristics of the event and individual, the reflection correlating two self-descriptions, two time dimensions of narrative ("before" and "after") as continuous intervals of individual self-identity, with each other.

When verbalizing all forms of autobiographical material in discursive practices, the most relevant tones are reflexive (42.37\%), emotional (22.7\%) and inspired (12.12\%) ones, and critical, ironic, nostalgic and arrogant tones act as additional ones.

A layered structure of $A M$ is correlated with the degree of semantic processing of autobiographical material and partly with its organizational forms (Nurkova, 2008), that is reflected in respective discursive practices. The analysis confirms that AM has a layered structure that includes specific episodes; memories of the fateful events; life themes (that represent the subject's significant life-time activity, indicate the succession of the stages of the subject's personal life, the whole integral view of his fate. 


\subsection{In accordance with culturally defined life scenarios the thematic keynotes implemented in autobiographical practices are correlated with personal meanings.}

Having identified in the studied material, the thematic keynotes (the regular objects of re-actualization) can be correlated with the thematic groups underlined by $\mathrm{H}$. Löfler (Löfler, 1988: 108), the most relevant of which are: 1) the life of the community or alliance (36.55\%); 2) festive occasions (birthday, wedding, etc.) (26.36\%); 3) the events of professional life (15.23\%); 4) educational sphere (10.15\%); 5) diseases, accidents (6.63\%). In the study the thematic keynotes underlined in discursive practices are partly correlated with stressors revealed by A.L. Eremin (Eremin, 2005) which affect the functions and ecology of intelligent systems that, in fact, are the points on the line of individual life which characteristics determine their presence and the most frequent re-actualization or conscious active replacement: leaving of their homes (24.33\%); changes in professional life (19.01\%); changes in social and financial status (12.82\%); trauma, disease, death (11.28\%), etc. These figures indicate how often re-actualization of the events is manifested in the formed episodes, but not their significance in the individual experience as the most important events in the individual's life happened only once (e.g. marriage, divorce, the loss of loved people, etc.). As the lists show, the thematic keynotes are focused on personal meanings determined by the subject's motives, needs and values.

\subsection{Appeal to AM is determined by individual motives; the discursive patterns of re-actualization of the past experience are defined by implemented functions of $A M$.}

The analysis of the linguistic material shows that appeal to the individual past is determined by different aims (see: Vasilevskaya, 2008) in accordance with what we can talk about discursive implementation of different AM functions. The most commonly manifested functions are pragmatic one (appeal to AM content to solve the current problems and plan the future actions; appeal to negative memories and implementation of the subject's position as an observer are prevailed); self-regulatory function (re-actualization of autobiographical material to control the individual mental state, to re-experience the fragments of the individual past; appeal to positive memories and the subject's position as a participant are dominated); communicative function (autobiographical content is used for making or developing contact; frequent reproduction of positive and negative memories and implementation of the subject's positions as an observer and actor are almost identical; the choice of position is defined by speaker's ideas of the desired result - differentiation of content or the subject's emotions (identity). Re-actualization of the fragment of the individual past from the position of the subject as an actor involves the verbalization of details of sensual perception, description of mental state, the subject's emotional experiences, and from the position of the subject as an observer it involves a distant, less emotional narrative without any details. The most relevant thematic keynotes within AM pragmatic function are "an individual and his characteristics", "content of conversation, written paper or their parts", "place, interior, location", "negative circumstances", "specific data", "neutral events and their participants", "assessment of the actions"; when manifesting the self-regulatory function the thematic keynotes are "positive experiences", "negative experiences", "mixed experiences"; within communicative function they are "events", "an individual", "place and its characteristics".

\section{Conclusion}

Taking the form of autobiographical narrative in early period of ontogenetic development of a preschooler, AM undergoes a difficult stage of its formation which is associated with the development of speech, the formation of the subject's discursive competences. Child's memories (the overcoming of child's amnesia) during the evolution of cognitive and linguistic system of a preschooler are generalized under the scheme which undergoes the following options (that is typical for the German-speaking partners in communication): a) who, what, when, where did; b) what, whom, who did; c) who did, what he did, where, when... + why; d) who, what, whom, /where, when/ did,... + why; e) who did, what he did, when (did); f) who did, what he did, where, when, what for, why,... + context (late stages of philological and genetic development).

The analysis of autobiographical practices of an adult shows the objectivity of AM functional and structural characteristics in discursive practices. The subsystem of autobiographical memory is interactive and inter-subjective, the discursive manifestation of its functions reflects valuable occupancy of its objects and AM correlation with emotional experiences. Various organizational forms of autobiographical material, AM layered structure and its functions, that in total determine discursive patterns, are manifested in discursive practices. The discursive practices mediate the AM formation and functioning, reorganizing the preverbal event of the individual past through the concepts fixed by language. The fragments of the individual past are organized and systematized as specific organizational forms which belong to the individual memory layers assuming different semantic processing and degree of schematization. The analysis of the 
thematic keynotes and linguistic means of their objectivity, the frequency of verbalization of memories about impressive events, specific episodes, the position of the subject as an actor and emotional tone of narrative allow to make a conclusion about the implementation of such formula of re-actualization of the individual past as "single - impressive self-centered" in the German linguistic culture.

\section{References}

Aljuscheva, A.R. (2012). Acquisition of cultural life scripts repertory as a factor of autobiographical memory macrostructure development. [Online] Available: http://psystudy.ru/index.php/num/2012v5n25/732-alyusheva25.html (April 2, 2015)

Baddeley, A.D. (1992). What is autobiographical memory? In: Theoretical perspectives on autobiographical memory. Dordrecht: Kluwer. pp. 13-29.

Bowden, E.M., Beeman, M.J. (1998). Getting the right idea: Semantic activation in the right hemisphere may help solve insight problems. In: Psychological Science. Vol. 9. N6, pp. 435-440.

Chernigovskaja, T.V., Deglin, V.L. (1986). Brain functional asymmetry and neural organization of linguistic competence. Brain and Language, Vol. 29. pp. 141-153.

CHILDES - Child Language Data Exchange System. Transcript Browser. [Online] Available: http://childes.psy.cmu.edu/browser/index. php (April 4, 2015)

Conway M.A., Rubin D.C. (1993). The structure of autobiographical memory In: Theories of memory. Hove, U.K.: Erlbaum. pp. 103-137.

Craik, F., Moroz, T., Moscovitsch M., Stuss, D., Winocur, G, Tulving, E., Kapur, S. (1999). In search of the self: a positron emission tomography study. In: Psychological Science. Vol. 10. pp. 26-34.

Decety, J., Chaminade, Th. (2003). When the self represents the other: A new cognitive neuroscience view on psychological identification. In: Consciousness and Cognition. Vol. 12. pp. 577-596.

Decety, J., Sommerville, J. (2003). Shared representations between self and other: a social cognition neuroscience view. In: Trends in Cognitive Science. Vol. 1. 527 p.

Devinsky, O. (2000). Right cerebral hemisphere dominance for a sense of corporeal and emotional self. In: Epilepsy and Behavior. Vol.1. pp. 60-73.

Downar, J. Crawley, A.P., Mikulis, D.J., Davis, K.D. (2002). A cortical network sensitive to stimulus salience in a neutral behavioral context across multiple sensory modalities. In: Neurophysiol, Vol. 87 (1). pp. 15-20.

DSAv - Deutsches Spracharchiv. [Online] Available: http://dsav-oeff.ids-mannheim.de/DSAv (April 4, 2015)

Eremin, A.L. (2005). Ecology and physiology of the intellectual systems, the patterns of informational ecology. In: Nogenesis and theory of intelligence. Krasnodar: SovKub. 356 p.

Fivush, R., Bauer, P.J. (2010). The Emergence of Recollection: How we learn to recall ourselves in the past. In: J.H. Mace (Ed.). The act of remembering: Towards an understanding of how we recall the past. Oxford. UK: Wiley-Blackwell. pp. 259-283.

Keenan, J.P., Nelson, A., O'Connor, M., Pascual-Leone, A. (2001). Self-recognition and the right hemisphere. In: Nature. (409). 305 p.

Löfller, H. (1988). Vergangenheit in mündlicher Überlieferung aus germanistischer Sicht. In: Vergangenheit in mündlicher Überlieferung. Stuttgart: Teubner. 345 p., pp. 100-113.

Lou, H.C., Luber, B., Crupain, M., Keenan, J.P., Nowak, M., Kjaer, T.W., Sackeim, H.A., Lisanby, S.H. (2004). Parietal cortex and representation of the mental self. Proc. Natl. Acad. Sci. U. S. A. Vol. 101. pp. 6827-6832.

Markowitsch, H.J. (1995). Anatomical Basis of Memory Disorders. In: Gazzaniga, M., S. (Ed.). The Cognitive Neuroscience. Cambridge. MA: MIT Press. pp. 665-679.

Nelson, K. (1991). Remembering and telling: A developmental story. In: Journal of Narrative and Life History. Vol 1. № 2-3. pp. 109-27.

Nelson, K. (1993). Explaining the Emergence of Autobiographical Memory in Early Childhood In: A.F. Collins, S.E. Gathercole, M.A. Conway, P. E. Morris (Hrsg.) Theories of Memory, Hove, UK: Erlbaum. pp. 355-385.

Nelson, K., Fivush R. (2004). The emergence of autobiographical memory: A social cultural developmental theory. In: Psychological Review. 111(2). pp. 486-511.

Nikanorova, L.V. (1998). Genesis of autobiographical story. [Online] Available: http://www.psychology.ru/lomonosov/tesises/gf.htm (April 2, 2015)

Nurkova, V.V. (2004). The role of autobiographical memory and the structure of personal identity. In: The world of psychology. № 2 (38). Moscow. pp. 77-86.

Nurkova, V.V. (2008). Analysis of the phenomenology of autobiographical memory within the framework of cultural-historical approach. In: Cultural-Historical Psychology. Issue 1, pp. 17-26.

Platek, S., Keenan, J., Gallup, G., Mohamed, F. (2004). Where am I? The neurological correlates of self and other. In: Cognitive Brain Research. Vol. 19. pp. 114-122.

Rotenberg V.S., Weinberg I. (1999). Human memory, cerebral hemispheres, and limbic system. A new approach. In: Genetic, Social and General Psychology Monographs, 125(1). pp. 45-70.

Shamne, N.L., Rebrina, L.N., Milovanova, M.V., Petrova, A.A. (2014). Phenomenon of memory and category of space: gnoseological and communicative status. In: XLinguae. European Scientific Language Journal. Vol. 7. Issue 3. pp. 32-49.

Vasilevskaya, K.N. (2008). The individual and typological features of autobiographical memory: abstract of diss.... candidate of psychological sciences. Moscow. 26 p.

Vygotskij L.S. (1996). Thinking and speech. Psychological research. M., Labirint. 419 p. 